\title{
France and Eastern Christians: beneath a controversial mobilisation
}

Camille Lons

\section{Abstract}

This paper explores the relationship between France and Eastern Christians while analysing how the rise of the Islamic State in 2014 has prompted French mobilisation in favor of Christian communities within the areas. Viewing Christians communities as the roots of their culture, French politicians and civil society organisations have come to the rescue of Eastern Christians. Despite this, the policies favoring Eastern Christians do not come without their own political agenda and ideological foundations. In turn, this challenges the neutrality of French humanitarianism.

Keywords: Eastern Christians, France, Mobilisation, Refugee Crises

To cite this paper: Camille Lons, "France and Eastern Christians: beneath a controversial mobilisation ", Civil Society Knowledge Center, Lebanon Support, June, 2016 . DOI: 10.28943/CSKC.002.40002. [ONLINE]:

https://civilsociety-centre.org/paper/france-and-eastern-christians-beneath-controversial-mobilisation

\section{Eastern Christians: between the Western imaginary and a diverse reality}

Since the uprising of the Islamic State in Syria and Iraq in summer 2014, French media has been overwhelmed by images coming from the Middle East, showing terrible scenes of violence and exile. Growing concern among politicians and the public regarding the security situation in the region has led to widespread messages of solidarity with the victims of violence, along with initiatives from civil society. An important component of French public opinion particularly demonstrated empathy toward the Christian communities whom the French consider to be the root of their own culture and who are often depicted in the media as being the target of Islamist atrocities.1 To assist victims, initiatives from both the French government and private associations thus began to spread, drawing upon old links between the French and Eastern Christians. However, this sudden reaction of solidarity has been perceived as controversial, as it challenges the supposed neutrality of humanitarianism, and raises many questions about the ideological foundations of such a mobilisation. Rather than being based on a profound understanding of the multifold Middle East crises, it seems that the movement in favour of Eastern Christians in France tends to be a projection of the national political agenda. Media and political discourses tend to build in France a "myth" of the Eastern Christian, presented as constantly persecuted by the Muslim majority, and whose culture and beliefs tend to be presented as the folkloric idealisation of a more authentic faith. What is the relationship between France and the Eastern Christians? How was the myth of the "Eastern Christian" in Western minds built? What does the current movement of solidarity refer to?

Before trying to analyse the current mobilisation for Eastern Christians in France, it is essential to analyse the long history of this relationship. Largely employed by French media and politicians, the term 
"Eastern Christians" refers, in fact, to a complex reality. The most widespread definition encompasses Christians belonging to the Oriental churches, which were created after successive schisms during the 5th and 6th centuries. Nevertheless, scholars may include in this definition Christians from a variable number of countries from the Middle East, Africa, Asia and Eastern Europe.2 Thus, "Eastern" refers to a blurred geographical space, that is originally defined in opposition to the Western world. The term of "Eastern Christians" is therefore not historically neutral and refers to an "orientalist" construction, as coined by Edward Said in 1978. 3 The Lebanese historian George Corm described the notion of "Eastern Christians" as a creation of Western powers at a moment when Europe and United States were restructuring the Middle East according to their own political and geostrategic interests. 4 In this vein, many researchers maintain that "Eastern Christians" should not be defined as the same global term since they cover a great diversity of individuals. Reducing "Eastern Christians" merely to their religious belonging completely excludes the economic, social, political and cultural contexts they live in. As George Corm states, Eastern Christians "are before anything Syrian, Lebanese, Egyptian or Jordanian, Iraqi or Palestinian; however they cannot be denominated collectively as 'Eastern Christians'”. $\underline{5}$

While the French media depicts "Eastern Christians"as being an excluded and persecuted community surrounded by an oppressive, Muslim majority, in reality, Eastern Christians are a central part of the societies they live in. Indeed, during the 19th century, Christian intellectuals such as Boutros alBoustani, Francis Marrash, Jorge Zaydan and Khalil Gibran, played a key role in the emerging Arab identity. $\underline{6}$ Even today, in countries such as Lebanon and Syria, and even Iraq until recently, Christian communities hold both political and economic positions of power. This is why the common distinction made between the Muslim world and the Christian world makes little sense. In many cases, Christian populations in Arab countries are far closer to Muslim populations of their respective countries than to Western Christians, even regarding the spiritual and ritualistic aspects of their life. In fact, often, cultural and religious syncretism can be observed between Muslim and Christian communities, as a result of their constant cohabitation.7 As Islam was born in a context very influenced by Christianity, the two religions have more common grounds than what is usually stated by thinkers of the "the Clash of Civilizations". $\underline{8}$

\section{Do Eastern Christians have "a problem with the West"?}

According to the historian Bernard Heyberger "it is seen as an evidence for everyone that Eastern Christians have a problem with Islam. But we usually forget that they also have one with the West" $\underline{9}$ Though France has been presenting its support to Eastern Christians in multifold ways, it has also often used these populations as a tool to defend its own interests in the region. Through the treaties of "capitulations" between Francis I of France and the Ottoman Sultan Suleiman the Magnificent around 1535, France provided support to Eastern Christians, but above all acquired great commercial advantages with a quasi monopole for the trade in the region.

Instead of having positive effects, French action towards Eastern Christians actually had negative repercussions in many cases. Since the time of the Crusades, the intervention of Western powers in the Middle East in the name of Christianity has been contributing to confusion and mistrust among Middle 
Eastern populations, making Christians appear as supporters of Western imperialism. Instead of protecting their perceived allies in the region, French support inadvertently reinforced discrimination against Christians which then led to an exodus of Christians from the region. 10.

By imposing such a religious vision of geopolitics in the region, even today, the French intervention has contributed to making sectarian divisions concrete.11 The tradition of diplomatic relations between France and Lebanese Maronites dates back to 1860. During the Sultan's bloody repression against Maronites, 12 Napoleon III sent his army and imposed a specific status for Christians in Mount Lebanon in 1861. Since then, the French have kept a tight diplomatic relationship with Lebanese Maronites.13

At the beginning of the Lebanese Civil War in 1975, French media and politicians immediately adopted a sectarian reading of the conflict, staging Christians and Muslims as opposing parties. This perception was of course very simplistic as the tensions resulted essentially from economic, social and political dissensions, much more than purely religious concerns. French media and politicians brought back the imagery of the "Eastern Christians" persecuted by Muslims, and indirectly contributed to reinforcing tensions between communities in Lebanon. 14 More recently, the rise of ISIS in Iraq and Syria has revived the old depiction of the persecuted Eastern Christians back to the limelight.

\section{The comeback of Eastern Christians on the French political agenda}

During summer 2014, French media started releasing images of violence and exile coming from Iraq and Syria, bringing back the old spectre of Christian persecution in the Middle East. Assyro-chaldeans, Greek-Catholic Melkites and syriac orthodox Christians all made the headlines of newspapers, with a renewed public interest in these secular communities and their traditions. The theme of Eastern Christians had already made its comeback in 2004 with the attacks of churches in Baghdad by Al Qaida. Many French organisations such as Fraternité Irak, SOS Chrétiens d'Orient and l'Association d'Entraide aux Minorités d'Orient (AEMO) had been created during this period to support Christian communities and their activities. Other organisations with more experience in the field,such as the Oeuvre d'Orient and the Aide à l'Eglise en Détresse (AED), noted this renewed interest from the French public. "People heard about our organisation with the news," explains Anne-Estelle Radenac from the Oeuvre d'Orient. "Some people even discovered there were Christians in the Middle East." Many movements of mobilisation were initiated by individuals and small associations, most of them being from the Catholic community. "Even if everybody is concerned by this issue, the public is essentially Catholic," recognises Priest William Marie Merchat, representative of the Oeuvre d'Orient. On social networks, numerous groups of support have emerged and the "noun" of Nazareens has been largely shared. The archbishop of Lyon Philippe Barbarin made several trips in Iraq in 2014 and called on French churches to mobilize. The archbishops of Paris and Marseille followed him in 2015, cosigning a statement. Many churches organised collective prayers, conferences and fundraising events.

Even if these movements of solidarity attest a sincere empathy and respond to real suffering from Christian communities, they rely on an incomplete and simplified understanding of Christians in the Middle East. Anne-Estelle Radenac insists on the fact that, despite the focus of Western media on the fate of Eastern Christians, many other communities in the region, suffering from the same situations as 
Christians, are being overlooked:

"Some media talked about 500 Christians being buried alive in August 2014, but they were in reality Yezidis. I don't say that Christians are not suffering, but their situation is different from the Yezidis for example, who have been killed by thousands while very few Christians have been killed until today. Many associations in France tend to manipulate information or focus only on Christians to mobilise donors." 15

Rodolphe Begue, from the association "Fraternité en Irak", makes the same remark concerning the easy manipulation of images and symbols to stir the mobilisation in France: "There is a photo that circulated a lot, showing three Christians crucified. It is a very strong symbol, but the problem is that it was three Shia, and it was in Syria."16

By omitting information and not explaining the complex political and economic issues that underlies sectarian tensions in the Middle East, many French media platforms and politicians tend to perpetuate religious interpretations of conflicts in the Middle East, though many scholars, such as George Corm, have been combatting such misinterpretations.17 Furthermore, this religious reading of conflict also silences centuries of cohabitation and interreligious dialogue that characterises the relationship between Christians and Muslims in the Middle East. "The situation should not make us forget this experience of living together that has been possible between Christians and Muslims in this region," explains William Marie Merchat.

The vision of Eastern Christians conveyed by the discourses of media and organisations tend to confine them in an orientalist and folkloric vision, not taking into account the great diversity of these communities on the field. They appear as the representatives of a millenary Christianism, timeless and authentic, that has not been perverted by secularisation. As figures of martyrdom, persecuted by an expansionist Islam, Eastern Christians embody all the fantasies and fears of French Catholics today.

\section{A very political humanitarian commitment}

The mobilisation of French politicians in favour of Eastern Christians is seemingly confusing as the French principle of "laïcité" does not allow an openly discriminatory attitude toward a specific religious community. However, in reality, French civil society is tightly linked to the political circles and issues of Eastern Christians, which ties in with crucial internal political debates of France. The debates center around the changing national identity and the relationship the country has with its Muslim minority.

Patrick Karam, founder of the Coordination for Eastern Christians in Danger (CHREDO), is a right-wing politician, and interministerial delegate for the former president Nicolas Sarkozy. His deep knowledge of the French political sphere helped him impose the issue of Eastern Christians onto the political agenda:

"We work closely with Laurent Fabius. We have 140 deputies and senators members of the CHREDO, which means we are able to ask written or oral questions in the Parliament to push the French 
diplomacy. I have a long experience in lobbying, I have a network, I know how the French political class works, I know how decisions are taken.We had to impose this thematic."18

In June 2014, the CHREDO managed to create a study group dedicated to Eastern Christians in the French Parliament. It also supported the initiative of different right-wing mayors to support Eastern Christians publicly, and helped the former Prime Minister François Fillon to launch a "great gathering for Eastern Christians" in June 2015.

Even though most the politicians committed to supporting Eastern Christians are right-wing, the cause was also taken up by the extreme right, through especially the NGO "SOS Chrétiens d'Orient". Although the NGO, created in 2013, presents itself as a non-political association working on the development of solidarity with Eastern Christians, it appears to be in reality extremely close to the French extreme-right. Its founder Charles de Meyer previously worked as a parliamentary assistant for the extreme-right deputy Jacques Bompart, and had been very active in the mobilisations against same sex marriage. The treasurer Benjamin Blanchard, also a collaborator with Jacques Bompart, is now working for the extreme-right eurodeputy Marie-Christine Arnautu.19 SOS Chrétiens d'Orient is also suspected to promote the Syrian regime of Bashar al-Assad. In July 2015, it organised the meeting between deputy Jean-Frédéric Poisson and Bashar al-Assad. If SOS Chrétiens d'Orient does not represent all the organisations involved in the protection of Eastern Christians, it is still an interesting example of the tight connections existing between many organisations and political parties, and how crisis can be manipulated to correspond to a specific political agenda.

This reviving of the cause of Eastern Christians by the French right and extreme right can be linked to the current political debate in France concerning Islam and immigration, as well as the "Christian" identity of the country. By defending Eastern Christians, right-wing politicians may find a way to gather their electorate and hence reinforce their position in the political arena. Indeed, many organisations and actors seemed to relate to the question of what is considered to be the true "roots" of French culture.

"The public is mainly Catholic. I meet also people not really committed to their faith, but they all feel that there is something going on with the roots," explains William Marie Merchat. "People discover that Eastern Christians are the roots of the Christian world. In the West, we are destroying these roots. There is a link to keep. When we know where we come from, we can know how to live and where to go." $\underline{20}$

Jean-Christophe Peaucelle, advisor of the Ministry of Foreign Affairs for religious issues, admits that the debates surrounding Islam in France and Eastern Christians are two sides of the same issue. Even so, he insists on the importance of not to falling into political propaganda and hate speech:

"Most of the news in France is related to Eastern Christians and Islam. In reality, they are two sides of the same issue. [...] It is the issue of living together that we are facing in both cases. If defending Eastern Christians becomes a way to express islamophobia, it means we miss totally the true debate."21

William Marie Merchat makes the same conclusion concerning this need to reopen interreligious dialogue in order to soothe the French current identity crisis: 
"I see more and more young Catholics feeling as a minority, and then insecure, and therefore develop a stronger identity. There are parties and movements playing with this - including inside the Church some traditionalist movements assimilate the persecution of Eastern Christians as a call for a new Crusade. There is a need to come back to clear roots, to help people give a meaning to their lives. Laïcite is not the suppression of religions but the permission to each religion to express itself in the respect of the country's traditions." 22

The debate over Eastern Christians gives opportunity to question the French model of laicite and its relationship with different religions. The French mobilisation for Eastern Christians seem to mark a turning point in humanitarian principles and approaches: while humanitarianism used to rely during the 19th century on religious charity, it has been secularising itself for the past two centuries. Most of the global humanitarian organisations today depict themselves as secular and use a very universalist discourse. 23 However, the movement of solidarity with Eastern Christians justifies itself through very religious and sectarian viewpoints, putting forward an idea of mandatory solidarity between people of the same religious community. This represents an interesting shift in organisations' discourse. For some observers, the choice to support Christians communities shows a progression of sectarianism, while for others, this position is better adapted to how many solidarity networks are working in the Middle East. Many studies about Muslim faith-based NGOs224 show a growing interest for religious reference in the humanitarian sector and the specific support religion can bring to the field.

\section{Conclusion}

The mobilisation of French actors for Eastern Christians in the context of the Syro-Iraqi crisis echoes many of the debates agitating contemporary French society. While all eyes seem to be set on the Middle East, the interpretation of the Eastern Christians' fate may be found in French internal political agendas and debates. Together, in the past few decades, the debate over the role of Catholicism in the French identity and the issue of immigration and French Muslims, have had a prominent place in the French political sphere, especially since the multiple terrorist attacks in 2015 . The tools of mobilisation and communication used by the associations involved in favor of Eastern Christians rely on symbols and representations specific to the French social identity. These tools sometimes appeal to the emotional aspect of mobilisation instead of developing a deep and nuanced knowledge of the supported populations. This correlation between the mobilisation for Eastern Christians and the French political agenda explains why associations are often extremely linked to the political class. However by placing religion in the center of their communication strategies and tools, these associations are undertaking a shift in humanitarianism that has been secularising itself since the 19th century. Is this change showing the increasing comeback of religion in international relations in general? The recent terrorist attacks recall the need to reopen this debate. For William Marie Merchat, "the interreligious dialogue is the key for living together, and the attacks have reminded the need for more dialogue." 25

- 1. Paul Balta, «L'exode des chrétiens d'Orient. », Confluences Méditerranée 2/2004 (N49), p. 161-165 ; Pierre Valognes, Vie et mort des chrétiens d'Orient. Des origines à nos jours, Paris, Fayard, 1994.

- 2. Eight countries for Jean-Pierre Valognes (Lebanon, Syria, Israel/Palestine, Jordan, Iraq, 
Egypt, Turkey; cf. Jean-Pierre Valognes, Vie et mort des Chrétiens d'Orient, Paris, Fayard, 1994), while Jean-Michel Cadiot includes also Ethiopia, Djibouti, Sudan, Armenia, Georgia, India (Jean-Michel Cadiot, Les Chrétiens d'Orient. Vitalité, souffrance, avenir, Paris, Salvator, 2010).

- 3. Edward Said, L'Orientalisme. L'Orient créé par l'Occident, Paris, Editions du Seuil, 2005.

- 4. Georges Corm, “ Où en est la présence chrétienne en Orient », dans Chrétiens d'Orient, Paris, L'Harmattan, 2008.

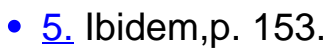

- 6. Antoine Fleyfel, Géopolitique des Chrétiens d'Orient, Paris, L'Harmattan, 2013.

- 7. Catherine Mayeur-Jaouen, Pélerinages d'Egypte. Histoire de la piété copte et musulmane, Xve-XXe siècle, Paris, Editions de l'EHESS, 2005.

- 8. Samuel Huntington, Le Choc des Civilisations, Paris, Odile Jacob, 1997.

- 9. Bernard Heyberger, "Les Chrétiens orientaux, entre I'Islam et l'Occident », in Les Chrétiens oubliés, La Revue des Deux Mondes, février 2015.

- 10. Antoine Fleyfel, Géopolitique des Chrétiens d'Orient, Paris, L'Harmattan, 2013

- 11. Georges Corm, «Pour une analyse profane des conflits », in Le Monde Diplomatique,février 2013, http://www.monde-diplomatique.fr/2013/02/CORM/48760

- 12. Eastern Christians were the target of violences and massacres committed first by Druzes in Mount Lebanon since March-July 1860, and then by Sunni in Damas between July 9 and 18, 1861. The attacks caused around 10,000 deaths and are considered as the starting point of emigration of Christians toward Latin America and ... Facing the absence of reaction from the sultan and the pressures of the French Catholic circles, the French Emperor Napoleon III initiated a European intervention. Cf. Henry Laurens, L'Orient arabe : arabisme et islamisme de 1798 à 1945, Armand Colin, 2002, 336 p.

- 13. Henry Laurens, Orientales, t.III, Paris, CNRS Editions, 2007.

- 14. Elizabeth Picard, «A l'épreuve de la guerre du Liban », in Bernard Heyberger (dir.), Chrétiens du monde arabe. Un archipel en terre d'Islam, Paris, Autrement, 2003.

- 15. Interview by the author with Anne-Estelle Radenac, in charge of the communication at the Oeuvre d'Orient, in February 24, 2015.

- 16. Interview by the author with Rodolphe Begue, student and general secretary of Fraternité Irak on February 23, 2015.

- 17. Georges Corm, Pour une lecture profane des conflits, Paris, La Découverte, 2012

- 18. Interview by the author with Patrick Karam, president of the CHREDO (Coordination Chrétiens d'Orient en Danger), in February 28, 2015.

- 19. "Comment l'association SOS Chrétiens d'Orient est noyautée par l'extrême droite', Libération, 21 mai 2015, http://www.liberation.fr/societe/2015/05/21/comment-I-association-sos-chretiens-d-orient-estnoyautee-par-I-extreme-droite 1313913 [last access 30/03/2015]

- 20. Interview by the author with the French Catholic priest William Marie Merchat, delegate of the Oeuvre d'Orient for the region of Gard (France), in May 27, 2015.

- 21. Interview by the author with Jean-Christophe Peaucelle, advisor for religious affairs of the Ministry of Foreign Affairs in May 19, 2015.

- 22. Interview by the author with the French Catholic priest William Marie Merchat, delegate of the Oeuvre d'Orient for the region of Gard (France), in May 27, 2015

- 23. Alastair Ager, "Faith and the Discourse of Secular Humanitarianism", Journal of Refugee 
Studies, Vol. 24, No. 3, Oxford University Press, 2011

- 24. Marie Juul Petersen, Islamizing Aid: Transnational Muslim NGOs After 9.11, VOLUNTAS: International Journal of Voluntary and Nonprofit Organizations, 23(1), 2012, 126-155; Marie Juul Petersen, Trajectories of transnational Muslim NGOs, Development in Practice, 2012, 22:5-6, 763-778; Jamie Furniss, Daniel Meier, « Le laïc et le religieux dans l'action humanitaire, une introduction », A contrario 2012/2 ( $\left.{ }^{\circ} 18\right)$, p. 7-36

- 25. Interview by the author with the French Catholic priest William Marie Merchat, delegate of the Oeuvre d'Orient for the region of Gard (France), in May 27, 2015. 